\title{
Penilaian Jasa Ekosistem Mangrove di Teluk Blanakan Kabupaten Subang
}

\section{(Valuation of Mangrove Ecosystem Services in Blanakan Bay, Subang District)}

\author{
Martini Dwi Indrayanti ${ }^{1,2^{\star}}$, Achmad Fahrudin $^{3}$, Isdradjad Setiobudiandi ${ }^{3}$ \\ (Diterima April 2015/Disetujui Juli 2015)
}

\begin{abstract}
ABSTRAK
Mangrove merupakan sumber daya alam yang berperan penting dalam memelihara keseimbangan antara ekosistem darat dan perairan. Oleh karena itu, ekosistem ini juga sebagai pendukung kehidupan yang perlu dijaga kelestariannya. Penelitian ini dilakukan di Teluk Blanakan yang tujuannya adalah: 1) Mengetahui luasan tutupan mangrove melalui analisis citra; dan 2) Melakukan analisis ekonomi terhadap jasa ekosistem. Luas penutupan mangrove diperoleh melalui analisis citra satelit dan nilai jasa ekosistem diperoleh melalui metode valuasi ekonomi. Valuasi ekonomi jasa ekosistem mangrove merupakan peubah penting dalam pengelolaan pesisir. Hasil analisis menunjukkan bahwa pada kurun waktu 2005-2012 mangrove mengalami penurunan tutupan luasan 5\%/tahun dan nilai jasa ekosistem mangrove di Teluk Blanakan adalah sebesar Rp3.815.790.110,97/tahun.
\end{abstract}

Kata kunci: jasa ekosistem, luasan tutupan, mangrove, Teluk Blanakan, valuasi ekonomi

\section{ABSTACT}

Mangrove is one of the natural resource that has an important role in maintaining the balance between landbased and aquatic ecosystems. Therefore the ecosystems are placed as one of the life-supporting ecosystems which is needed to be preserved. This study was held in Blanakan Bay with objectives were: 1) To describe the covered area of mangrove ecosystem; and 2) To calculate the value of mangrove ecosystem services. Mangrove covered area was obtained through satellite image analysis while ecosystem services was anlyzed by economic valuation method. Economic valuation for mangrove ecosystem services is an important variable in coastal management. The result showed that mangrove covered area was decreasing by $5 \%$ per year during the period of 2005-2012 while the value of the ecosystem services in the study area was Rp3.815.790.110,97/year.

Keywords: Blanakan Bay, covered area, economic valuation, ecosystem services, mangrove

\section{PENDAHULUAN}

Mangrove sebagai salah satu komponen ekosistem pesisir berperan penting, baik dilihat dari sisi ekologi, yaitu peranan dalam memelihara produktivitas perairan maupun dalam menunjang kehidupan ekonomi penduduk sekitarnya. Bagi wilayah pesisir, ekosistem ini, terutama sebagai jalur hijau di sepanjang pantai/muara sungai sangatlah penting untuk nener/ikan dan udang serta mempertahankan kualitas ekosistem perikanan, pertanian, dan permukiman yang berada dibelakangnya dari gangguan abrasi, instrusi, dan angin laut yang kencang.

Ekosistem mangrove merupakan ekosistem yang

\footnotetext{
${ }^{1}$ Direktorat Sumber Daya Ikan, Direktorat Jenderal Perikanan Tangkap, Kementerian Kelautan dan Perikanan, Gedung Mina Bahari II Lantai 10, Jalan Medan Merdeka Timur No. 16, Jakarta Pusat.

2 Program Magister Pengelolaan Sumber Daya Pesisir dan Lautan, Sekolah Pascasarjana, Institut Pertanian Bogor, Kampus IPB Darmaga, Bogor 16680.

3 Departemen Manajemen Sumber Daya Perairan, Fakultas Perikanan dan IImu Kelautan, Institut Pertanian Bogor, Kampus IPB Darmaga, Bogor 16680.

*Penulis Korespondensi: E-mail: martini.dwi88@gmail.com
}

subur, karena degradasi serasah mangrove memasok unsur hara bagi lingkungannya. Unsur hara kemudian dimanfaatkan oleh plankton dalam fotosintesis, sehingga perairan mempunyai produktivitas yang tinggi. Hal ini menyebabkan kelimpahan organisme pada tingkatan trofik dalam rantai makanan menjadi tinggi pula. Ketersediaan plankton dan benthos di perairan tersebut merupakan makanan bagi ikan. Dengan kondisi tersebut, ikan memanfaatkan ekosistem perairan mangrove sebagai daerah mencari makan, memijah, dan pembesaran. Jadi mangrove mempunyai nilai ekologis yang tinggi untuk menunjang keberlangsungan ekosistem akuatik di kawasan mangrove Blanakan.

Menurut Bengen (2000) bahwa ekosistem mangrove memiliki fungsi antara lain sebagai: 1) Pelindung pantai dari gempuran ombak, arus, dan angin; 2) Tempat berlindung, berpijah atau berkembang biak, dan daerah asuhan berbagai jenis biota; 3) Penghasil bahan organik yang sangat produktif (detritus); 4) Sumber bahan baku industri bahan bakar; (5) Pemasok larva ikan, udang, dan biota laut lainnya; serta 6) Tempat pariwisata. Sumber daya biologi unik ini merupakan salah satu dari lima potensi yang menjadikan Indonesia sebagai salah 
satu negara terbesar setelah China, India, USA, dan Uni-Eropa sebagaimana visi Indonesia 2030 (Soeprobowati et al. 2012)

Sedangkan menurut Baran dan Hambrey (1999), ekosistem mangrove memiliki beberapa fungsi, yaitu: 1) Sebagai tempat hidup dan mencari makan berbagai jenis ikan, kepiting, udang, dan tempat ikan-ikan melakukan proses reproduksi; 2) Menyuplai bahan makanan bagi spesies-spesies didaerah estuari yang hidup dibawahnya karena mangrove menghasilkan bahan organik; 3) Sebagai pelindung lingkungan dengan melindungi erosi pantai dan ekosistemnya dari tsunami, gelombang, arus laut, dan angin topan; 4) Sebagai penghasil biomas organik dan penyerap polutan di sekitar pantai dengan penyerapan; 5) Sebagai tempat rekreasi khususnya untuk pemandangan kehidupan burung dan satwa liar lainnya; 6) Sebagai sumber bahan kayu untuk perumahan, kayu bakar, arang, dan kayu perangkap ikan; 7) Tempat penangkaran dan penangkapan bibit ikan; dan 8) Sebagai bahan obat-obatan dan alkohol.

Saat ini pengelolaan sumber daya mengacu pada konsep pembangunan berkelanjutan dengan menjaga keseimbangan antara pertumbuhan ekonomi, partisipasi aktif masyarakat serta kualitas sumber daya alam. Pemanfaatan sumber daya alam dan pembangunan wilayah pesisir yang tidak seimbang dapat memberikan dampak yang kurang menguntungkan bahkan dalam jangka panjang. Banyak penelitian yang menyimpulkan bahwa mangrove secara alami tidak menguntungkan jika dibandingkan dengan mengkonversi untuk tujuan pengembangan budi daya perikanan. Presentasi hutan mangrove dan tambak pola tumpang sari sudah tidak sesuai lagi dengan ketentuan yang dikeluarkan oleh Perum Perhutani. Fakta menunjukkan bahwa banyak wilayah di mana mangrove dikonversi secara total untuk budi daya tambak. Terdapat sebagian penggarap yang membuka hutannya lebih dari $20 \%$ untuk dijadikan tambak (Mahendra 2007).

Udang berasal dari dua sumber yang berbeda, terdapat udang yang ditangkap langsung dari laut serta udang yang dibudidayakan di wilayah pesisir. Seiring dengan perkembangan budi daya udang yang terus meningkat, udang menjadi komoditi yang benilai tinggi di perdagangan dunia. Hal ini menjadikan mangrove sebagai ekosistem yang dikorbankan untuk budi daya udang komersial (Martinez 2001). Holing (1973) menyatakan bahwa hampir semua sistem alam mempunyai karakteristik berubah sepanjang waktu dan bahwa jika manusia mencoba menstabilkan alam untuk kepentingannya akan menyebabkan kondisi stabil pada jangka pendek dan malapetaka pada jangka panjang.

Fungsi ekologis ekosistem mangrove amat penting kontribusinya bagi nilai ekonomi mangrove itu sendiri. Valuasi ekonomi dapat digunakan untuk mentransformasi nilai ekologis ini menjadi nilai ekonomi dengan mengukur nilai moneter dari seluruh barang dan jasa yang dihasilkan (Fauzi 2000). Keberadaan mangrove berkaitan erat dengan tingkat produksi perikanan, hampir $80 \%$ dari seluruh jenis ikan laut yang dikonsumsi manusia berada di ekosistem mangrove (Saenger et al. 1983).

Nilai jasa ekosistem mangrove atau indirect use value merujuk pada nilai yang dirasakan secara tidak langsung terhadap barang dan jasa yang dihasilkan oleh sumber daya alam dan lingkungan. Indirect use value juga lebih bersifat sulit diukur (less tangible) karena lebih didasarkan pada preferensi terhadap lingkungan ketimbang pemanfaatan langsung. Manfaat jasa lingkungan dari ekosistem mangrove dihitung melalui manfaat tidak langsung ekosistem mangrove sebagai perlindungan pantai, feeding ground, pariwisata, manfaat pilihan (option value), dan manfaat keberadaan (existence value) ekosistem mangrove. Penelitian ini bertujuan untuk mengetahui luasan tutupan mangrove melalui analisis citra, dan melakukan analisis ekonomi terhadap jasa ekosistem mangrove.

\section{METODE PENELITIAN}

Penelitian dilakukan pada bulan Januari-Maret 2013 di Kecamatan Blanakan (Teluk Blanakan), Kabupaten Subang, Provinsi Jawa Barat. Pengambilan contoh dilaksanakan di Desa Cilamaya Girang, Blanakan, dan Muara. Contoh diambil acak bertingkat (stratified random sampling) dengan dasar stratifikasinya adalah kegiatan pemanfaatan sumber daya pesisir (Fahrudin 1996).

Penelitian dilaksanakan dengan menggunakan studi kasus (case study). Pengambilan contoh responden dilakukan dalam rangka menghitung manfaat ekosistem mangrove sebagai pariwisata dan keberadaan ekosistemnya sendiri. Data primer diperoleh melalui wawancara langsung dengan responden pemakai ekosistem dan diambil dengan menggunakan kuesioner dan pengamatan di lapangan (observasi). Sedangkan data sekunder diperoleh dari instansi/lembaga yang terkait.

Luasan penutupan mangrove diketahui melalui pengolahan data citra. Pengolahan data dikelompokan pra-pengolahan (preprocessing); penajaman citra; klasifikasi tutupan lahan; pemisahan objek mangrove; analisis indeks vegetasi; dan klasifikasi kerapatan tajuk mangrove. Data kemudian dipakai untuk melakukan overlay antara peta sebaran hasil klasifikasi tutupan lahan dengan peta kerapatan hasil analisis indeks vegetasi untuk mendapatkan peta kerapatan sebaran mangrove.

Nilai dari manfaat tidak langsung adalah nilai yang dihasilkan dari pemanfaatan secara tidak langsung, sebagai penahan abrasi atau pemecah ombak (break water) (Rp/tahun), mencari makan (feeding ground) bagi biota perairan, serta manfaat pariwisata. Nilai manfaat tidak langsung dirumuskan sebagai berikut:

MTL = MTL1 + MTL2 + MTL3

Keterangan:

$\mathrm{MTL}=$ Manfaat tidak langsung 
MTL1 = Perlindungan pantai

MTL2 = Manfaat feeding ground

MTL3 = Pariwisata

Estimasi manfaat hutan mangrove sebagai penahan abrasi didekati dengan pembuatan beton pantai setara dengan fungsi sebagai penahan abrasi. Manfaat perlindungan tersebut dirumuskan sebagai berikut:

$$
\mathrm{MTLi}=\mathrm{C} \times \mathrm{L}
$$

Keterangan:

$\mathrm{MTLi}=$ Manfaat tidak langsung perlindungan pantai

C = Biaya rehabilitasi $(\mathrm{Rp} / \mathrm{ha})$

$\mathrm{L} \quad \quad=$ Luas wilayah mangrove (ha)

Estimasi manfaat feeding ground juga menggunakan asumsi penyebaran manfaat yang sebanding dengan luas mangrove dan didekati dengan rumus:

$\mathrm{MLi}=\mathrm{Pi} \times \mathrm{Qi}$

Keterangan:

$\mathrm{MLi} \quad=$ Manfaat langsung

$\mathrm{Pi} \quad=$ Harga komoditas yang berlaku di pasar $(\mathrm{Rp})$

Qi = Jumlah komoditas yang diekstraksi selama satu tahun

Manfaat pariwisata didekati dengan travel cost method (TCM), yaitu metode yang pertama kali digunakan untuk menduga nilai ekonomi sebuah komoditas yang tidak memiliki nilai pasar (nonmarket goods) (Adrianto et al. 2004). Nilai ekonomi rekreasi diduga dengan menggunakan biaya perjalanan wisata (TCM), yang meliputi biaya transport pulang pergi, dan pengeluaran lain selama di perjalanan dan di dalam kawasan wisata (konsumsi, parkir, tiket masuk, dan lain lain).

Manfaat pilihan didekati dengan mengacu pada nilai keanekaragaman hayati hutan mangrove, yaitu US $\$ 1,500 / \mathrm{km}^{2} /$ tahun atau US $\$ 15 /$ ha/tahun (Ruitenbeek 1991; Fahrudin 1996). Secara matematis, manfaat pilihan dirumuskan sebagai:

$$
\mathrm{MP}=\mathrm{Nb} \times \mathrm{L}
$$

Keterangan:

MP = Manfaat pilihan

$\mathrm{Nb}=$ Nilai keanekaragaman hayati $(\mathrm{Rp} / \mathrm{ha})$

$\mathrm{L} \quad=$ Luas wilayah mangrove (ha)

Manfaat keberadaan dihitung dengan menggunakan rumus sebagai berikut:

$\mathrm{MK}=\sum_{\mathrm{i}=1}^{\mathrm{N}} \frac{\mathrm{MKi}}{\mathrm{N}}$

Keterangan:

MK = Manfaat keberadaan

$\mathrm{MKi}=$ Manfaat keberadaan dari responden $\mathrm{ke}-\mathrm{i}$

$\mathrm{N}=$ Total responden

\section{HASIL DAN PEMBAHASAN}

\section{Luasan dan Presentase Penutupan Mangrove}

Berdasarkan hasil analisis, terlihat bahwa tambak memiliki luasan terbesar, yaitu sekitar $80 \%$ dari total luas lahan (Gambar 1). Pada kurun waktu 2005-2012 terjadi peningkatan luasan lahan tambak sebesar 5\% (sekitar $700 \mathrm{~m} /$ tahun), dari $84 \%$ pada tahun 2005 sampai $89 \%$ pada tahun 2012. Sebaliknya, mangrove di Kecamatan Blanakan pada kurun waktu 2005-2012 mengalami penurunan tutupan luasan sebesar 5\% (sekitar $700 \mathrm{~m} /$ tahun) dan penurunan terbesar terjadi di Desa Jayamukti sebesar 36\% (sekitar $95 \mathrm{~m} / \mathrm{tahun}$ ). Pada kurun yang sama terjadi peningkatan luasan tutupan sebesar $21 \%$ (sekitar $38 \mathrm{~m} /$ tahun) yang terjadi di Desa Cilamaya Girang. Sama halnya dengan mangrove, luas tutupan lahan semak juga mengalami penurunan sekitar $200 \mathrm{~m} /$ tahun.

Berdasarkan data dari BPKPH Pamanukan (2012) diketahui bahwa luasan mangrove terbesar berada di Desa Blanakan, yaitu 303,25 ha dan luasan terkecil di Desa Cilamaya Girang, yaitu 166,69 ha. Melalui hasil analisis Citra Landsat tahun 2005 dan 2012 diperoleh peta penutupan mangrove Teluk Blanakan, Kabupaten Subang. Hasil analisis menunjukkan bahwa terjadi pengurangan tutupan yang cukup drastis pada periode 2005-2015 di mana pengurangan luasan terbesar terjadi di Desa Blanakan, dari 62,80\% menjadi $20,03 \%$. Luasan dan persentase penutupan disajikan dalam Tabel 1.

Hasil klasifikasi pemetaan kerapatan mangrove yang dilakukan melalui analisis citra, didapatkan total luas di lokasi penelitian pada tahun 2005, yaitu $1.023,75$ ha yang terbagi atas: mangrove dengan kategori jarang sebanyak 697,36 ha $(68,11 \%)$, kategori sedang sebanyak 185,74 ha $(18,14 \%)$, dan kategori lebat sebanyak 140,65 ha $(13,74 \%)$. Sedangkan pada tahun 2012, yaitu 909,71 ha yang terbagi atas: mangrove dengan kategori jarang sebanyak 623,23 ha $(68,51 \%)$, kategori sedang sebanyak 174,48 ha $(19,18 \%)$, dan mangrove kategori lebat sebanyak 112 ha $(12,31 \%)$. Secara keseluruhan dapat disimpulkan bahwa di lokasi penelitian banyak ditemukan vegetasi mangrove dengan kerapatan kategori jarang.

\section{Penilaian Ekonomi Sumber Daya \\ Manfaat Tidak Langsung (Non Direct Use Value)}

Manfaat fisik merupakan manfaat sebagai penahan abrasi yang diestimasi dari pembuatan bangunan air, yaitu pemecah gelombang (break water). Berdasarkan analisis harga satuan pekerjaan (AHSP) bidang pekerjaan umum yang dikeluarkan oleh BALITBANG PU (2012), bahwa biaya pembangunan fasilitas pemecah gelombang (break water) ukuran $150 \times 20 \times 10 \mathrm{~m}$ (panjang $\times$ lebar $\times$ tinggi) sebesar Rp1.563.217.000,00. Panjang pantai ekosistem hutan mangrove di wilayah Teluk Blanakan adalah $6.800 \mathrm{~m}$, maka biaya pembuatan pemecah gelombang dengan daya tahan 20 tahun seluruhnya adalah Rp70.865.837.333,00. Nilai tersebut bila dibagi dalam 20 tahun diperoleh sebesar Rp3.543.292.866,65/tahunnya. Jadi, untuk menggantikan fungsi perlindungan pantai ekosistem mangrove di Teluk Blanakan adalah Rp3.543.292.866,65/tahun.

Di samping manfaat fisik, manfaat tidak langsung lainnya adalah manfaat biologi. Manfaat biologi dari pemanfaatan tidak langsung sebagai penyedia pakan alami bagi ikan. Manfaat ini didekati dengan meng- 

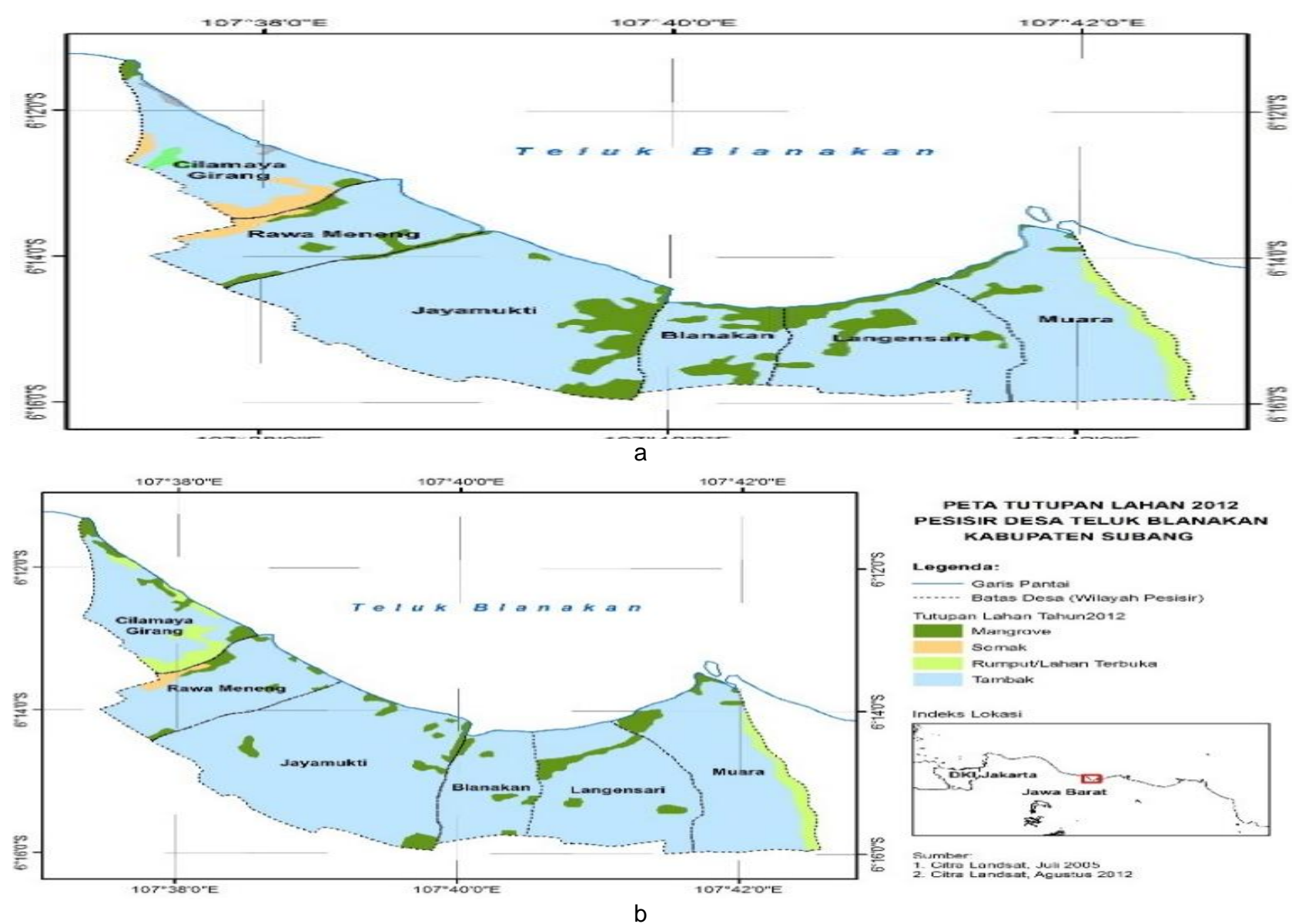

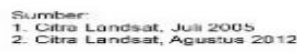

Gambar 1 Peta tutupan lahan Kecamatan Blanakan (a) 2005; (b) 2012 (Sumber: BIG Citra Landsat 2005 dan 2012 , diolah 2013).

Tabel 1 Luasan dan persentase penutupan mangrove

\begin{tabular}{cccc}
\hline \multirow{2}{*}{ Desa } & *Luas & \multicolumn{2}{c}{${ }^{* *}$ Persentase tutupan } \\
& mangrove (ha) & \multicolumn{2}{c}{ mangrove $(\%)$} \\
\cline { 3 - 4 } & 2012 & 2005 & 2012 \\
\hline Cilamaya & 166,69 & 10,77 & 41,41 \\
Girang & & & \\
Blanakan & 303,25 & 62,80 & 20,03 \\
Muara & 312,4 & 26,44 & 38,56 \\
\hline & 782,34 & &
\end{tabular}

Sumber: * KPH Pamanukan (2012)

** BIG: Citra Landsat 2005 dan 2012, diolah 2013

gunakan persamaan regresi luasan hutan mangrove dan produksi udang seperti yang dilakukan oleh Suryaperdana (2011), yaitu:

$$
\begin{array}{ll} 
& Y=3.783 x+23,33 \\
\text { Dimana: } & Y=\text { Produksi udang }(\mathrm{Kg}) \\
& \mathrm{X}=\text { Luas mangrove }(\mathrm{Ha})
\end{array}
$$

Persamaan di atas memiliki nilai R2 sebesar $90,2 \%$ yang artinya nilai produksi dapat dijelaskan oleh luas mangrove sebesar $90,2 \%$ dan mempunyai korelasi positif sebesar 94,9\%. Dengan kata lain, hubungan antara luasan mangrove dengan produksi adalah berbeda nyata, di mana semakin luas mangrove maka semakin tinggi nilai produksinya. Hal ini karena semakin luas mangrove, maka semakin banyak nutrient yang dihasilkan sebagai makanan bagi udang itu sendiri.
Luas kawasan hutan mangrove di Teluk Blanakan (3 desa sampling) adalah 782,34 ha. Diperkirakan luasan tersebut dapat diperoleh produksi udang sebesar 2.982,72 kg/tahun. Hasil wawancara dengan responden didapatkan harga pakan Rp13.000,00/kg dan kebutuhan pakan $2 \mathrm{~kg}$ per $\mathrm{kg}$ udang. Berdasarkan data tersebut, maka dapat diperoleh nilai manfaat mangrove sebagai penyedia pakan alami dengan mengalikan produksi udang dengan harga pakan dan kebutuhan pakan per kg udang, didapat nilai sebesar Rp77.550.720,00/tahun.

Manfaat hutan yang bersifat jasa (nonconsumptive of mangrove service) adalah manfaat sebagai objek wisata. Aktivitas rekreasi ini biasanya ramai pada hari sabtu dan minggu. Berdasarkan hasil perhitungan, didapat nilai manfaat dari kegiatan wisata ini, yaitu sebesar Rp59.536.679,52/tahun.

Berdasarkan hasil analisis, nilai manfaat tidak langsung terbesar diperoleh melalui manfaat mangrove sebagai perlindungan pantai. Rekapitulasi dari hasil identifikasi jenis dan nilai manfaat tidak langsung ekosistem mangrove, dapat dilihat pada Tabel 2.

\section{Nilai Manfaat Pilihan (Manfaat Keanekaragaman Hayati)}

Manfaat pilihan dianalisis dengan menggunakan perhitungan dari manfaat keanekaragaman hayati 
(biodiversity) seperti yang dikemukakan oleh Ruitenbeek (1991). Nilai manfaat keanekaragaman hayati di Teluk Bintuni, Papua adalah US $\$ 1.500 \mathrm{~km}^{2}$ (US $\$ 15 /$ ha)/ha/tahun. Nilai tukar rupiah terhadap dollar pada saat penelitian, yaitu sebesar Rp9.768,00 (Bank Indonesia, Maret 2013) sedangkan luas kawasan mangrove di lokasi penelitian adalah 782,34 ha. Sehingga nilai biodiversity yang diperoleh adalah sebesar Rp114.628.456,80, seperti disajikan pada Tabel 3.

\section{Nilai Manfaat Keberadaan}

Nilai rataan WTP yang diperoleh dari 132 responden, yaitu sebesar Rp26.564,00/ha/tahun. Nilai rata-rata WTP sebesar Rp26.564,00/ha/tahun dikalikan dengan luas ekosistem mangrove 782,34 ha, sehingga nilai manfaat keberadaan sebesar Rp20.782.388,00. Hasil analisis menunjukkan bahwa tingkat pendidikan responden berpengaruh terhadap nilai keberadaan.

\section{Nilai Jasa Ekosistem Mangrove}

Nilai jasa ekosistem mangrove (value of mangrove ecosystem services) di Kecamatan Blanakan, Kabupaten Subang merupakan penjumlahan dari nilai-nilai manfaat yang telah diuraikan di atas, yaitu nilai manfaat tidak langsung (indirect use value), nilai manfaat pilihan (option value), dan nilai manfaat keberadaan (existence value). Selanjutnya dilakukan kuantifikasi manfaat mangrove secara keseluruhan sebagaimana tersaji pada Tabel 4 .

Pada Tabel 4 dapat dilihat bahwa manfaat tidak langsung memiliki persentase paling besar, yaitu $96,45 \%$ dengan nilai sebesar Rp3.680.379.266,17/tahun. Nilai yang cukup besar ini disebabkan besarnya nilai dari manfaat mangrove

Tabel 2 Nilai total manfaat tidak langsung

\begin{tabular}{lr}
\hline \multicolumn{1}{c}{ Uraian } & Jumlah (Rp/tahun) \\
\hline Manfaat perlindungan pantai & $3.543 .292 .866,65$ \\
Manfaat feeding ground & $77.550 .720,00$ \\
Manfaat pariwisata & $59.536 .679,52$ \\
\hline Nilai manfaat tidak langsung & $3.680 .379 .266,17$ \\
\hline
\end{tabular}

Tabel 3 Nilai manfaat keanekaragaman hayati

\begin{tabular}{lr}
\hline \multicolumn{1}{c}{ Uraian } & \multicolumn{1}{c}{ Nilai } \\
\hline Nilai biodiversity di Teluk Bintuni & 15 \\
(US $\$$ ) & \\
Kurs (1 US \$ $=$ Rp) - Maret, 2013 & 9.768 \\
Luas mangrove (ha) & 782,34 \\
\hline Nilai biodiversity per tahun & Rp114.628.456,80 \\
\hline
\end{tabular}

Tabel 4 Nilai ekonomi total ekosistem mangrove

\begin{tabular}{lrc}
\hline \multicolumn{1}{c}{ Kategori manfaat } & $\begin{array}{c}\text { Nilai manfaat } \\
\text { bersih } \\
\text { (Rp/Tahun) }\end{array}$ & $\begin{array}{c}\text { Proporsi } \\
(\%)\end{array}$ \\
\hline Manfaat tidak langsung & $3.680 .379 .266,17$ & 96,45 \\
Manfaat pilihan & $114.628 .456,80$ & 3,00 \\
Manfaat keberadaan & $20.782 .388,00$ & 0,54 \\
\hline Total nilai jasa ekosistem & $3.815 .790 .110,97$ & \\
\hline
\end{tabular}

sebagai pelindung pantai. Selanjutnya, kuantifikasi manfaat lainnya diperoleh berturut-turut nilai manfaat pilihan sebesar Rp114.628.456,80/tahun (3\%), dan nilai manfaat keberadaan sebesar Rp20.782.388,00/tahun (0,54\%). Berdasarkan luas mangrove di petak sampling, yaitu 782,34 ha, maka nilai jasa ekosistem mangrove di wilayah Teluk Blanakan adalah Rp3.815.790.110,97/tahun.

\section{KESIMPULAN}

Berdasarkan hasil analisis diperoleh bahwa tambak memilki luasan terbesar, yaitu sekitar $80 \%$ dari total luas lahan. Sebaliknya, mangrove di Kecamatan Blanakan pada kurun waktu 2005-2012 mengalami penurunan luasan tutupan sebesar 5\% (sekitar $700 \mathrm{~m} /$ tahun) dan penurunan terbesar terjadi di Desa Jayamukti sebesar 36\% (sekitar $95 \mathrm{~m} / \mathrm{tahun}$ ). Pada kurun yang sama terjadi peningkatan luasan tutupan sebesar $21 \%$ di Desa Cilamaya Girang. Dengan demikian, dapat dipastikan bahwa kondisi saat ini sudah tidak sesuai dengan anjuran Perhutani di mana komposisi yang ideal adalah $80 \%$ mangrove dan $20 \%$ tambak. Manfaat tidak langsung memiliki persentase paling besar, yaitu Rp3.680.379.266,17/tahun. Nilai ini diperoleh dari manfaat ekosistem mangrove sebagai perlindungan pantai. Fakta ini mengkonfirmasikan manfaat dan fungsi ekosistem mangrove sebagai sumber daya ekonomi maupun ekologi sehingga pengelolaannya penting dilakukan.

\section{DAFTAR PUSTAKA}

Adrianto L, Mujio, Wahyudin Y. 2004. Modul Pengenalan Konsep dan Metodologi Valuasi Ekonomi Sumber Daya Pesisir dan Laut. Bogor (ID): Pusat Kajian Sumber Daya Pesisir dan Lautan - Institut Pertanian Bogor.

Baran E, Hambrey J. 1999. Mangrove Conservation and Coastal Management in Southeast Asia: What Impact on Fishery Resources?. Marine Pollution Bulletin. 37(8-12): 431-440. http://doi.org/d38zm9

[BALITBANG PU] Badan Penelitian dan Pengembangan Pekerjaan Umum. 2012. Pedoman Bahan Konstruksi Bangunan dan Rekayasa Sipil: Analisis Harga Satuan Pekerjaan (AHSP) Bidang Pekerjaan Umum. Jakarta (ID): Kementerian Pekerjaan Umum.

Bengen DG. 2000. Pedoman Teknis Pengenalan dan Pengelolaan Ekosistem Mangrove. Bogor (ID): Pusat Kajian Sumber Daya Pesisir dan Lautan Institut Pertanian Bogor.

[BIG] Badan Informasi Geospasial. 2005. Citra Landsat Teluk Blanakan, Kabupaten Subang, 
Provinsi Jawa Barat. Jakarta (ID): Badan Informasi Geospasial.

[BIG] Badan Informasi Geospasial. 2012. Citra Landsat Teluk Blanakan, Kabupaten Subang, Provinsi Jawa Barat. Jakarta (ID): Badan Informasi Geospasial.

Fahrudin A. 1996. Analisis Ekonomi Pengelolaan Lahan Pesisir Kabupaten Subang, Jawa Barat. [Tesis]. Bogor (ID): Institut Pertanian Bogor.

Fauzi A. 2000. Persepsi terhadap Nilai Ekonomi Sumber Daya. Makalah pada Pelatihan untuk Pelatih, Pengelolaan Pesisir Terpadu. Bogor, November 2000. Bogor (ID): Institut Pertanian Bogor.

Holing CS. 1973. Resilience and Stability of Ecological Systems. Annual Review of Ecology and Systematics. 4: 1-23.

Mahendra PO. 2007. Tingkat Pendapatan Masyarakat Dalam Pengelolaan Tumpang Sari Empang Parit di Hutan Mangrove. [Skripsi]. Bogor (ID): Institut Pertanian Bogor.

Martinez-Alier J. 2001. Ecological Conflics and Valuation - Mangrove vs, Shrimp in The Late 1990's. Journal Environmen and Planning; 4/2001UHE/UAB-16/05/2001. Barcelona (ES): Universitat Autonoma de Barcelona.

Ruitenbeek HJ. 1991. Mangrove Management: An Economic Analysis of Management Options with a Focus on Bintuni Bay, Irian Jaya. EMDI/KLH, Jakarta (ID).

Soeprobowati TR, Suedy SWA, Gell P. 2012. Diatom Stratigraphy of Managrove Ecosystem on The Northern Coast of Central Java. Journal of Coastal Development. 15(2): 197-208.

Suryaperdana Y. 2011. Keterkaitan Lingkungan Mangrove Terhadap Produksi Udang dan Ikan Bandeng di Kawasan Silvofishery Blanakan, Subang, Jawa Barat. [Skripsi]. Bogor (ID): Institut Pertanian Bogor. 